IRA-International Journal of Management \& Social Sciences

ISSN 2455-2267; Vol.06, Issue 01 (2017)

Pg. no. 37-44

Institute of Research Advances

http://research-advances.org/index.php/RAJMSS

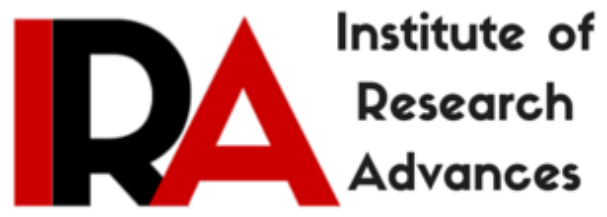

\title{
Capacity Building through Nature Tourism at Southeast Rajasthan
}

Dr. Surabhi Srivastava

Post Doctoral Researcher

School of Heritage, Tourism, Archaeology and Museology,

University of Kota, Kota, Rajasthan, India.

Type of Review: Peer Reviewed.

DOI: http://dx.doi.org/10.21013/jmss.v6.n1.p6

\section{How to cite this paper:}

Srivastava, S. (2017). Capacity Building through Nature Tourism at Southeast Rajasthan. IRA-International Journal of Management \& Social Sciences (ISSN 24552267), 6(1), 37-44. doi:http://dx.doi.org/10.21013/jmss.v6.n1.p6

(C) Institute of Research Advances

\section{(cc) BY-NC}

This work is licensed under a Creative Commons Attribution-Non Commercial 4.0 International License subject to proper citation to the publication source of the work.

Disclaimer: The scholarly papers as reviewed and published by the Institute of Research Advances (IRA) are the views and opinions of their respective authors and are not the views or opinions of the IRA. The IRA disclaims of any harm or loss caused due to the published content to any party. 


\begin{abstract}
Rajasthan is known for its forts, palaces, desert, culture and also its flora and fauna. The tourism department focuses its policies and marketing strategies around these attractions. Tourists from all over the world visit the sanctuary and surroundings to experience and explore the natural beauty of the place. The present paper presents the natural wealth of south east region of the state which is completely unexplored by the tourists and the tourism department. The region is travelled only by the explorers and adventurers. The researcher visited all these sites and explored the natural beauty for tourism development at this region. Under this paper the researcher developed a model for capacity building through tourism development of natural sites of a region.
\end{abstract}

Key Words: Capacity Building, wildlife, flora \& fauna, nature tourism, adventurer.

\title{
Introduction:
}

India is home to world's largest wild tigers population and has got unique assemblage of globally important endangered species like Asiatic lion, Asian Elephant, One-horned Rhinoceros, Gangetic River Dolphin, Snow Leopard, Kashmir Stag, Dugong, Gharial, Great Indian Bustard, Lion Tailed Macaque etc.

Wildlife conservation and management in India is currently facing a myriad of complex challenges that are both ecological and social in nature. Issues such as habitat loss/fragmentation, overuse of biomass resources in the context of biotic pressures, increasing human-wildlife conflicts, livelihood dependence on forests and wildlife resources, poaching and illegal trade in wildlife parts and products, need for maintaining a broad base of public support for wildlife conservation exemplify and characterize the contemporary wildlife conservation scenario in India.

Sanctuary is an area which is of adequate ecological, faunal, floral, geomorphological, natural or zoological significance. The Sanctuary is declared for the purpose of protecting, propagating or developing wildlife or its environment. Certain rights of people living inside the Sanctuary could be permitted. Further, during the settlement of claims, before finally notifying the Sanctuary, the Collector may, in consultation with the Chief Wildlife Warden, allow the continuation of any right of any person in or over any land within the limits of the Sanctuary.

Wildlife sanctuaries are the natural area where wildlife is protected and preserved is called wildlife sanctuary. These places provide suitable living conditions to the wild life. Killing, poaching, or capturing of wildlife animals is strictly prohibited in the wildlife sanctuaries. These places mainly consist of landscapes, mountains forests and broad leaf forests with limited human activities being permitted in the sanctuary.

National Park is an area having adequate ecological, faunal, floral, geomorphologic, natural or zoological significance. The National Park is declared for the purpose of protecting, propagating or developing wildlife or its environment, like that of a Sanctuary.

Biosphere reserves are areas of terrestrial and coastal ecosystems which promote the conservation of biodiversity with its sustainable use. They are internationally recognized within the framework of UNESCO's Man and Biosphere (MAB) programme and nominated by national governments. The Ministry of Environment and Forest provides financial assistance to the respective State governments for conservation of landscape and biological diversity and cultural heritage. Biosphere reserves serve in some ways as 'living laboratories' for testing out and demonstrating integrated management of land, water and biodiversity. 
Spanning an area of about $\mathbf{3 , 4 2 , 0 0 0 ~ s q ~} \mathbf{~ k m}$, located in north-west India, Rajasthan is among the largest of the country's states and is remarkably rich in wildlife, its vast size and latitudinal variations (sea level to over $1,700 \mathrm{~m}$ ) have provided it with varied vegetation- from the semi-evergreen forests of Mt Abu to the almost barren or dry scrub grasslands of the desert and from the dry deciduous thorn forests of the Aravalli hills to the wet marshes of Bharatpur. Rajasthan is basically a combination of two things that make it the ideal choice for special interest holiday destination - the amazing variety of flora and fauna at its countryside, and the historic nature of fantastic architectural heritage that dots its landscape. It is difficult to find any other place in India that much of variety of color in terms of attire, architecture, and customs. It is really fascinating education where such a large number of people integrate with their environment.

\section{Nature tourism in Rajasthan}

Geographically, Rajasthan can be divided into four regions, each distinctive - the desert in the north and west, the Aravalli hills in the middle, the alluvial Indo-Gangetic plains in the east, and the Vindhyan hills and the Deccan trap in the south and south-eastern parts of the state-with ecosystems that support a variety of wildlife. Till a hundred years ago the Asiatic lion, now confined to the Gir forests of Gujarat, and the cheetah, now extinct in India, were found in many parts of the state. Sightings of herds of over a thousand antelopes was not usual. The range and number of these antelopes has declined with the increase in human population and the ploughing of marginal lands-yet, large herds can still be spotted in the state's non-forest areas. Tigers and their prey animals, deer and wild bqar, are essentially forest animals and are, therefore, confined to the Aravalli and Vindhyan hills. Two protected regions have been included under Project Tiger. Although the tiger is an elusive animal, yet the chances of seeing one in the dry deciduous forests of Rajasthan is better than in most other tiger reserves.

The leopard, also called panther in India, an adaptable animal, is usually found in the forest areas as well as in the open, degraded forest areas with rocky outcrops adjoining towns and villages. The cunning predator finds it easy to prey on unguarded village dogs, goats, donkeys, calves and poultry.

Besides the two big cats, five lesser cats-caracal, jungle cat, fishing cat, desert cat and rusty spotted catinhabit the state. The caracal, found in both the forest and the desert, is a graceful feline with a sandy coloration and black tufted ears. Once trained for hunting doves, pigeons, partridges and other birds by the cheetah-trainers of Jaipur, this agile hunter has now become rate, occasionally sighted in Ranthambhore and Sariska. There have been recent reports of sightings of the rusty spotted cat for the first time in Sariska. It is possible that it is also present in other, similar areas though no such reports are available. The jungle cat is common in most protected areas as well as in the wastelands. The distribution of the desert cat is confined to the arid parts of the state, whereas the best place to spot a fishing cat is the Keoladeo Ghana national park, Bharatpur.

Objectives: the present study is about the natural resources of southeast region of Rajasthan. Following are the objectives of the research conducted:

1. To explore the eco trails of the region.

2. To study and analyse the natural wealth of the region.

3. To create capacity building through natural tourism within the region.

\section{Research Methodology:}

The research is completely exploratory with the objective to create new avenues for nature tourism in south east Rajasthan. The researcher visited the area and met all the people related to the wildlife directly or indirectly. Unstructured questionnaire were formed and responses were recorded. 


\section{Hadoti Region; Study area}

The Chambal dominating the hadoti region of Rajasthan is a visitor's paradise. The place has varied wildlife ranging from small insects to huge animals. The track meandered through lush green trees, forceful streams and rocky patches through the Chambal area is a pleasurable sight to cherish.

The districts of Kota. Bundi, Baran and Jhalawar have five wildlife sanctuaries and one Great Indian bustard hunting closed area. A number of excellent Bird watching sites are suggested for those who wish to see resident and migratory birds in their natural habitat.

Darrah Sanctuary- It is situated between two parallel running hills of Mukandara range. The Panther is the top predator surviving in Darrah. The Sloth bear, Hyena, Scaly ant eater, Jungle cat, Four horned antelope, Sambhar Spotted deer, Bluebull and Civets are frequently sighted.

The Darrah National Park is one of the most popular national parks in Rajasthan. It was established in 2004 and comprises of three wildlife sanctuaries namely, the Darrah Wildlife Sanctuary, the Chambal Wildlife Sanctuary and the Jaswant Sagar Wildlife Sanctuary.

The national park has large stretches of forests which were formerly part of the Maharaja of Kota's hunting grounds. Spread over an area of $250 \mathrm{sq} \mathrm{km}$, the wildlife sanctuary is situated at a distance of 50 $\mathrm{km}$ from the town of Kota. The sanctuary was officially declared as a protected zone in 1955. It is home to a number of species including the wild boar, deer, nilgai, cheetah and wolves.

The natural beauty of the region is beyond description. Furthermore, it also has a very rich cultural history. There is a very beautiful fort also within the premises of the sanctuary. The Jenana Khana of the fort is worth visiting because of its architectural beauty. The Sun Temple in Jharipatan is another destination worth visiting during a trip to the Darrah National Park.

The River Chandrabhaga flows very close to the national park and there are a number of ancient temples, dating back to the 7th and 8th centuries that are situated along the banks of the river.

Mukundara National Park: in the state was once the hunting ground of the erstwhile rulers. The animals found here include the wolf, sloth bear, Sambar, Caracal and the Panther. The graceful Chambal river glides through a thickly wooded forest area, adjacent to the dark and green hill ranges.

The Mukundara Hills Tiger Reserve covers a zone of $759 \mathrm{sq} \mathrm{km}$ and is the dwelling place 50 tigers. The Mukundara Hills Tiger Reserve is arranged at the southeastern visitor of Kota in Rajasthan. This thickly populated tiger store is the third biggest store in the state. It was in the past known as Mukundara Hills National Park and has been announced as a tiger save in the year 2012 by the Government of India.

The Jawahar Sagar sanctuary- boundary with Darrah and Chambal Gharial sanctuary and also their flora and fauna. The Panther, Wild boar and the birds of prey can be easily sighted here.

National Chambal Gharial Sanctuary-It is a rare riverine sanctuary of India. The length and the bank of the Chambal river between Jawahar sagar dam in Rajasthan. The highly endangered Marsh crocodile and endemic Indian Indian Gharial have ever since flourished in the river.

The National Chambal Sanctuary is situated on the River Chambal, at the point where the borders of the three states Rajasthan, Madhya Pradesh and Uttar Pradesh meet. The sanctuary was first declared to be in Madhya Pradesh in 1978.

Now, there is a narrow stretch of eco-reserve which is managed and administered by the three states. The sanctuary is also called the National Chambal Gharial Wildlife Sanctuary and is dedicated to the conservation of critically endangered gharials, the red crowned roof turtle and the threatened Ganges river dolphin. The sanctuary is protected under the country's Wildlife Protection Act of 1972. 
The sanctuary is home to several species such as the Indian Wolf, striped hyena, smooth coated otter, mugger crocodiles, and others. It is also home to eight of the 26 rare turtle species including the crowned river turtle, three striped roof turtle and Indian narrow headed softshell turtle.

The mammalian species include hedgehog, flying fox, hares, porcupines, Northern Palm Squirrels, Indian Gazelle, Blackbucks, nilgai, sambar, wild boar, jungle cats, Indian grey mongoose, Indian small mongoose, and common palm civet.

The main attractions of the sanctuary are the gharials, crocodiles, fresh water dolphins and rare turtles and these make the National Chambal Sanctuary one of the most exotic wildlife sanctuaries in Rajasthan.

There are several activities that are offered to visitors at the National Chambal Sanctuary. Visitors can hire boats with guides at the sanctuary and enjoy photographing the muggers, gharials and crocodiles. Guests can also enjoy walking trails in ravines and along the river to closely observe the wildlife and the way of life in the jungle more closely.

The Ater Fort is a dilapidated but extremely beautiful heritage site within the sanctuary. The fort, which was built by Bhadauria kings, is situated along the Chambal River and can be reached by jeep or boat.

Accommodation is available at forest Rest Houses in Bah and Chakkar Nagar. There are several commercial hotels and lodges near the sanctuary. The nearest airport and railway station is at Agra. Boating and visiting arrangements at the sanctuary can be done by contacting the Conservator of Forests in Kota.

Ramgarh Sancturay in Bundi: is single, compact and possess a large ecosystem in the zone. It falls under the subsidiary edaphic type of tropical dry deciduous forest. The fauna includes the panther, sloth bear, the hyena, Sambhar, Cheetal, the blue bull(Nilgai) an porcupines. It is a corridor to Ranthanbore, which makes the wild animals visit the area quite often for breeding.

Ramgarh Vishdhari Sanctuary, a famous one among the Wildlife Sanctuaries and National Parks in Rajasthan that lies on the main Nainwa road, $45 \mathrm{KMs}$ away from Bundi. Lined by dry deciduous forests with a numerous number of trees like Khair, Salar, Khirni, Ber,Babool, Mango and Dhok, the park lets every visitor to feel the state rejuvenation and being closer to nature again.

The sanctuary was notified in the year 1982 featured by the large ecosystem and it forms a passage for Ranthambore National Park. It takes 50 kilometres to reach Ramgarh from Bundi and 88 kilometres from Kota via Bundi.

Sorsan Great Indian Bustard Hunting Closed Area- It is situated in Baran district and can be easily approached from Kota. It has undulating grassland which is ideal for Great Indian bustard, Chinkara and blue buck. The temple of Brahmani mata also attracts large number of devotees and a fair is held during auspicious days.

Shergarh Sanctuary- Situated on the banks of Parban river, the Sanctuary is famous for its Panthers, Crocodiles and mighty Mahseer fishes.

Flora: Shergarh Wildlife Sanctuary is rich in floral species. Species such as Dhok (Anngoeissus pendula), Khair (Acacia catechu), Teak (Tectona grandis) are present in this Sanctuary. Many species of plants are available in this region. Shergarh Wild life Sanctuary consists of endangered and rare plants.

Fauna: Includes various habitats like Wild Boars, Hyena, Tigers, Sloth Bear, Leopards, Chinkara, Sambar, Endemic Deer and Chitals. 


\section{Bird watching in Hadoti-}

The migratory season for the birds, rich ecology of the Hadoti with lush green grasslands, dry deciduous forests and wetlands of Bundi, Kota, Baran, and Jhalawar were all thronged by numberous colourful birds. These winged creatures had made their presence felt with their musical chorus, sporting actions and had attravted the attention of the people. The areas like Sorsan, Amalsara, Nayana, Seemliya, Udaipuria are the places to catch a glimpse of these winged creatures. The Ruddy shell duck, Comduck, Tufted poachards, common coot were found in good numbersbut the flamingo are in less in number.

Bird researcher and photographer reported that in last two years mostly the birds seen are tufted duck, Eurasian Roller, Siberian stonechat, pied bushchat, black redstart, sandpipers, common redshanks and plovers stints. Bean goose was a rare sight and had delighted many bird watchers.

Another wildlife warden, Prithvi singh Rajawat from Guda Nathawthan, Bundi, reported that Painted stork can be seen near Ram nagar lake, Bardha Dam, Abhay Sagar and at other dams bird watching will be a great fun.

The demoiselle cranes, pelicans, Bar headed goose are also present in good numbers at Kanak Sagar, Talwas lake and Ram Sagar lakes of Bundi district.

Another wildlife scholar, Vitthal Sanashyaya claimed that Birds like Comduck, Chinese coot, pintail, waders and red crested poacher visited in recent years at different places of Hadoti region.

The Dams, Reservoirs, Tanks land Rivers of Hadoti offer some excellent Bird watching opportunities. The reservoir of Kota barrage, Rana Pratap sagar dam are huge wetlands and support a healthy population of resident and migratory birds

\section{Analyses and interpretation:}

During expedition the beautiful sites of hadoti region, the researcher explore the nearby villages, talk to them about the problems related to the wildlife. Then she met with the forest department and trying to understand the real situation of the flora and fauna of the region for tourism development.

She developed \& proposed a model to the department of forest and tourism as to develop nature tourism which will be helpful for the inhabitants and also the sustain our natural resources. 
STAKEHOLDERS BENEFITED BY NATURE TOURISM

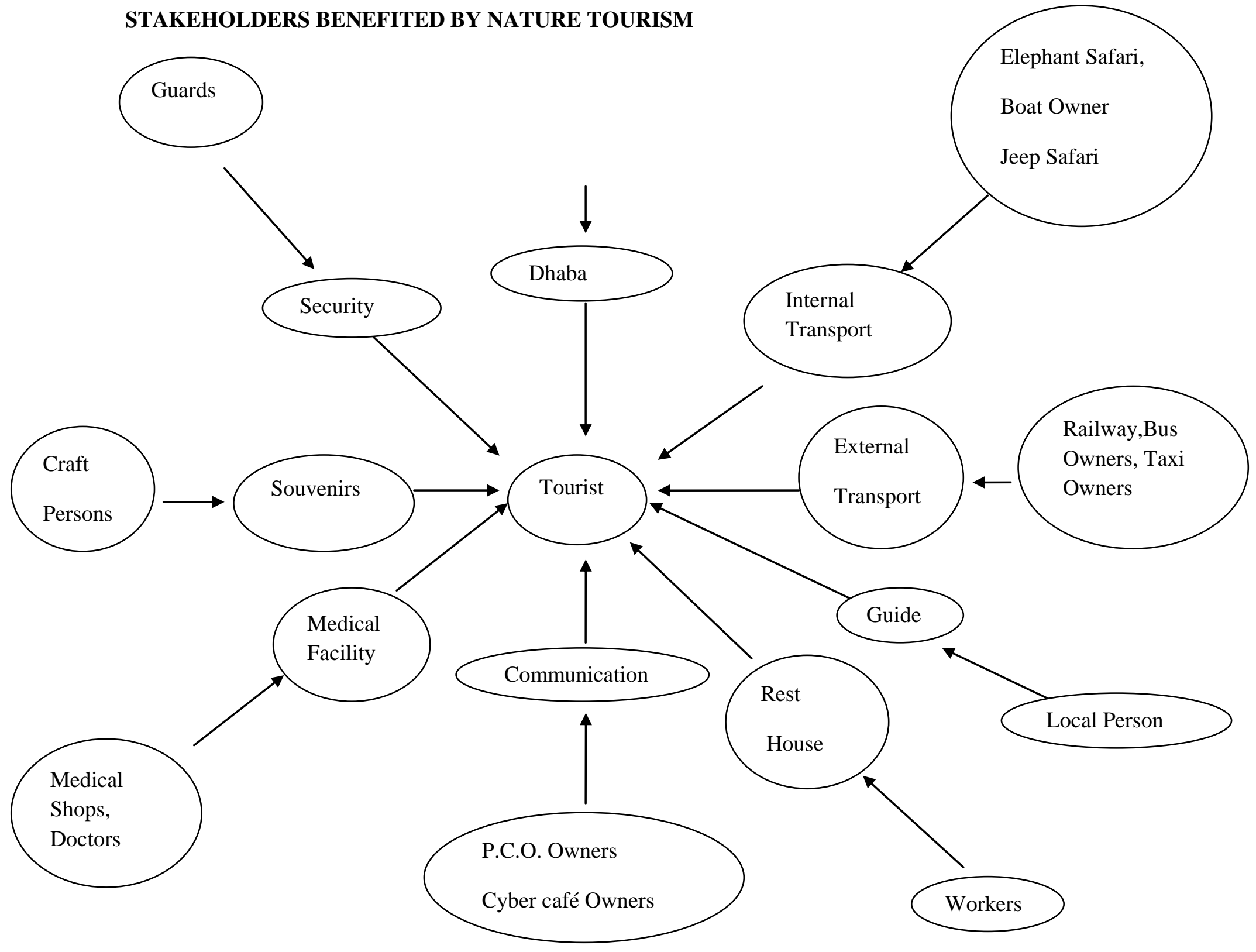


Target tourist would be only nature lovers and nature professionals. Developing tourism at these sites should be in a sustainable way.

\section{Analyses of the field Survey:}

The study conducted at various sites of sanctuaries. Though these areas are undertaken by the government but it becomes the shuttle cock between the forest department and tourism department. Inhabitants of these areas are poor and mostly have no source of earning. These people are either milkmen or bound to leave their village for daily bread. They are very familiar with the plants existed there and also feel easy to deal with the animals. And these two things are the key of developing Nature tourism.

\section{Conclusion:}

The natural heritage of a place provides an ample opportunity to the native people for self employment through developing natural tourism i.e. eco trails, wildlife safari, different adventurous sports, wildlife photography, bid watching etc.

Through government support \& little training with community involvement would be helpful in conservation of natural resources. This may also help in creating capacity building at their habitat. The model will be helpful to understand and implement in developing natural tourism in Hadoti region.

\section{REFERENCES}

1. Colin Michael Hall Pro-poor tourism: who benefits?: perspectives on tourism and poverty reduction Channel View Publications, 15-Sep-2007

2. Vittorio Gerosa Tourism: A Viable Option for Pro-Poor Growth in Africa? Economic Commission for Africa Economic Policy Research Center Kampala, Uganda 23-24 June 2003

3. Dilys Roe, Caroline Ashley, Sheila Page and Dorothea Meyer, Tourism and the Poor: Analysing and Interpreting Tourism Statistics from a Poverty Perspective, March 2004

4. Xavier Cattarinich Pro-poor tourism initiatives in developing countries: Analysis of secondary case studies April 2001

5. Caroline Ashley, Harold Goodwin and Dilys Roe, Pro-poor tourism: Expanding opportunities for the poor. PPT Policy Briefing No 1. (4pp). April 2001.

6. Harold Goodwin Pro-Poor Tourism Opportunities for Sustainable Local Development published by: Deutsche Stiftung für internationale Entwicklung (DSE) 